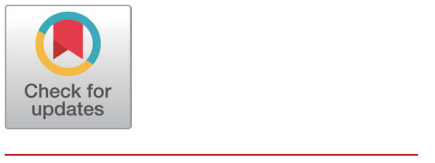

Received: May 31, 2021

Revised: July 19, 2021

Accepted: August 25, 2021

${ }^{+}$Corresponding author

Kwan-Sik Min

Institute of Genetic Engineering,

Hankyong National University, Ansung

17579, Korea.

Tel: +82-31-670-5421

E-mail:ksmin@hknu.ac.kr

Copyright @ $\odot 2021$ The Korean Society of Developmental Biology.

This is an Open Access article distributed under the terms of the Creative Commons Attribution Non-Commercial License (http://creativecommons.org/licenses/ by-nc/4.0/) which permits unrestricted non-commercial use, distribution, and reproduction in any medium, provided the original work is properly cited.

ORCID

Munkhzaya Byambaragchaa

https://orcid.org/0000-0002-0277-1816

Seung-Hee Choi

https://orcid.org/0000-0002-9550-6113

Dong-Wan Kim

https://orcid.org/0000-0002-7241-2982

Kwan-Sik Min

https://orcid.org/0000-0002-5451-3085

Conflict of interests

The authors declare no potential conflict of interest.

Acknowledgements

Not applicable.

Authors' contributions

Conceptualization: Min KS.

\section{Constitutive Activating Eel Luteinizing Hormone Receptors Induce Constitutively Signal Transduction and Inactivating Mutants Impair Biological Activity}

\author{
Munkhzaya Byambaragchaa', Seung-Hee Choi' ${ }^{2}$ Dong-Wan Kim', and \\ ${ }^{\dagger}$ Kwan-Sik Min ${ }^{1,2}$ \\ 'Institute of Genetic Engineering, Hankyong National University, Ansung 17579, Korea \\ ${ }^{2}$ School of Animal Life Convergence Science, Hankyong National University, Ansung 17579, Korea
}

\section{Abstract}

In contrast to the human lutropin receptor ( $h L H R$ ) and rat LHR (rLHR), very few naturally occurring mutants in other mammalian species have been identified. The present study aimed to delineate the mechanism of signal transduction by three constitutively activating mutants (designated M410T, L469R, and D590Y) and two inactivating mutants (D383N and Y546F) of the eel LHR, known to be naturally occurring in human LHR transmembrane domains. The mutants were constructed and measured cyclic adenosine monophosphate (cAMP) accumulation via homogeneous time-resolved fluorescence assays in Chinese hamster ovary (CHO)-K1 cells. The activating mutant cells expressing eel LHR-M410T, L469R, and D590Y exhibited a 4.0-, 19.1-, and 7.8-fold increase in basal cAMP response without agonist treatment, respectively. However, inactivating mutant cells expressing D417N and Y558F did not completely impaired signal transduction. Specifically, signal transduction in the cells expressing activating mutant L469R was not occurred with a further ligand stimulation, showing that the maximal response exhibited approximately $53 \%$ of those of wild type receptor. Our results suggested that the constitutively activating mutants of the eel LHR consistently occurred without agonist treatment. These results provide important information of LHR function in fish and regulation with regard to mutations of highly conserved amino acids in glycoprotein hormone receptors.

Keywords: Eel luteinizing hormone (LH) receptor, Constitutively activating mutation, Inactivating mutation, Signal transduction

\section{INTRODUCTION}

The luteinizing hormone receptor (LHR) is a member of the family of the 7 transmembrane $\mathrm{G}$ protein-coupled receptors (GPCRs), one of the largest gene families (Kudo et al., 1996). In particular, the LHR and follicle-stimulating hormone receptors (FSHRs) form a subgroup of the glycoprotein 
Data curation: Byambaragchaa M.

Formal analysis: $\mathrm{Choi} \mathrm{SH}$.

Software: Kim DW.

Writing-original draft: Byambaragchaa M.

Writing-review \& editing: Min KS.

Ethics approval

This article does not require IRB/IACUC approval because there are no human and animal participants. hormone receptors (Segaloff \& Ascoli, 1993; Ascoli et al., 2002). The LH receptor (LHR) gene has been associated with an abundance of naturally occurring mutations related to reproductive failures in mammals (Meehan \& Narayan, 2007; McGee \& Narayan, 2013). Many naturally occurring constitutively activating/or inactivating mutations of both human LHR (hLHR) and hFSHR have been described (Kraaij et al., 1995; Tao et al., 2000; Wu et al., 2000; Tao, 2006; Althumairy et al., 2020).

The first mutation reported is hLHR-D578Y (equivalent to D590Y in eel LHR) in transmembrane VI (Shenker et al., 1993). Since the original report of D578Y, additional mutations have been reported, including M398T (equivalent to M410T in eel LHR) in located in the second transmembrane helix (Ignacak et al., 2000), L457R (equivalent to L469R in eel LHR) in the transmembrane III (Latronico et al., 1998). The hLHR-L457R mutant was first identified on the basis that cells expressing this mutant displayed remarkably basal cyclic adenosine monophosphate (cAMP) levels. However, cells expressing the L457R mutant were unresponsive to further hormonal stimulation (Zhang et al., 2005 , 2007; Latronico \& Segaloff, 2007 ). The rat LHR (rLHR)-D556H mutation (rLHR-D556H; equivalent to the hLHR-D578H mutation) has also been shown to result in a marked increase in the basal cAMP response (Meehan \&Narayan, 2007). Although the inactivating rLHR-D383N (equivalent to D417N in eel LHR) and -R442H mutations have been reported to not affect the binding of the human chorionic gonadotropin (hCG), they do impair signal transduction (Dhanwada et al., 1996). We have also previously reported that the rLHR-D383N and Y524F (equivalent to Y558F in eel LHR) mutations were found to be signal impairing mutations (Min et al., 1998).

Recent research studies from our laboratory have elucidated the signal transduction of the eel LHR (Byambaragchaa et al., 2018) and eel FSHR (Kim et al., 2016, 2019) on deglycosylated ligands. In recently, we also first reported in fish species that eel FSHR-D540G mutant exhibited a highly increase in the basal cAMP response (Byambaragchaa et al., 2020). Although the activation effects of these mutants have been relatively well demonstrated in hLHR, very less is known about the signal transduction leading to the activation and inactivation in fish LHR.

Thus, this study aimed to determine these mechanisms by analyzing three constitutively activating (M410T, L469R, and D590Y in eel LHR), and two inactivating (D417N and Y558F in eel LHR) mutations known as highly conserved regions of transmembrane domains among the mammalian LHRs. Here, we report that the basal cAMP response was constitutively involved in activating eel LHRs, but the inactive mutants impaired the signal transduction.

\section{MATERIALS AND METHODS}

\section{Materials}

Polymerase chain reaction (PCR) reagents and endonucleases were purchased from Takara (Osaka, Japan). Oligonucleotides were synthesized by Genotech (Dajeon, Korea). The pcDNA3 mammalian expression vector, Chinese hamster ovary (CHO)-suspension (CHO-S) cells, MAX transfection reagent, Lipofectamine ${ }^{\mathrm{TM}}-3000$, Freestyle $\mathrm{CHO}$ medium, and antibiotics (penicillin and streptomycin) were obtained from Invitrogen (Carlsbad, CA, USA). The pGEM-T easy cloning vector was purchased from Promega (Madison, WI, USA). CHO-K1 cells were obtained from the Japanese Cancer Research Resources Bank (JCRB, Tokyo, Japan). A homogeneous time-resolved fluorescence (HTRF) cAMP assay kit was purchased from Cisbio (Codolet, France). Monoclonal antibodies (5A11, 11A8, and 14F5) and rec-eel LH from CHO-K1 cells were produced in our lab, as previously reported (Kim et al., 2016). The horseradish peroxidase (HRP) labeling of the 
8A11 monoclonal antibody was generously performed by Medexx (Seongnam, Korea). Eel LHR cDNA was cloned from eel ovaries and testes, as previously reported (Byambaragchaa et al., 2020). QIAprep-Spin plasmid kits were purchased from Qiagen (Hilden, Germany). Disposable spinner flasks were purchased from Corning (Corning, NY, USA). Centrifugal Filter Devices were purchased from Amicon Bio (Billerica, MA, USA). All other reagents used in this experiment were obtained from Sigma-Aldrich (St. Louis, MO, USA) or Wako Pure Chemicals (Osaka, Japan). The procedures and protocols used in this study were ethically reviewed and approved in accordance with the guidelines of the Hankyong National University committee (Number: 2018-03-01).

\section{Site-directed mutagenesis of active and inactive sites}

An overlap extension PCR strategy was used to create the activating and inactivating mutants in eel LHR cDNA as described previously (Byambaragchaa et al., 2020). Two different sets of PCR primers were used to amplify each mutant fragment. In step 1, the first set of fragments were amplified using forward and reverse primers (mutation primer). The second set of fragments were then amplified using forward (mutation primer) and reverse primers. In step 2, the amplified fragments (first and second set of fragments) from step 1 were used as templates to amplify the completely mutated fragments. The primer sequences used in these experiments are shown (Table 1). The full-length PCR products synthesized in step 2 were cloned into a pGEM-T easy vector. Plasmids were extracted and sequenced to confirm the presence of the mutations. A schematic representation of the naturally occurring mutation sites for the 3 activating (M410T, L469R, and D590Y) and 2 inactivating (D417N and Y558F) mutants in eel LHR is shown in Fig. 1.

\section{Vector construction}

cDNAs encoding wild type (WT) and mutant eel LHR were digested with the Eco $R I$ and Xho $I$ restriction enzymes. The resulting fragments were then ligated into the pcDNA3 and pCORON1000 SP VSV-G expression vector, as previously described (Byambaragchaa et al., 2018). Plasmids were then purified, and the presence of the correct insert was confirmed through analysis with restriction enzymes. Finally, we constructed a total of 6 receptor genes, including WT eel LHR, M410T, L469R, D590Y, D417N, and Y558F.

Table 1. List of primers used to construct eel LHR mutants

\begin{tabular}{lll}
\hline \hline & \multicolumn{1}{c}{ Primer name } & \multicolumn{1}{c}{ Primer sequence } \\
\hline 1 & Eel LHR-wt forward & 5'-ATGAATTCATGTCCAATCTGCTCTTGTGGACGATG-3' EcoRI site \\
2 & Eel LHR-wt reverse & 5'-CCTCGAGTTATTTAGGACCTCTGTTGAGAAT-3' Xhol site \\
3 & M410T forward & 5'-TCTCCCGCTTCCTCACGTGCAACCTGGCCTT-3' \\
4 & M410T reverse & 5'-AAGGCCAGGTTGCACGTGAGGAAGCGGGAGA-3' \\
5 & L469R forward & 5'-TGTCCGTCTACACCCGGACCGTCATCACCCT -3' \\
6 & L469R reverse & 5'-AGGGTGATGACGGTCCGGGTGTAGACGGACA-3' \\
7 & D590Y forward & 5'-TGCTCATATTCACCTACTTCCTGTGCATGGC-3' \\
8 & D590Y reverse & 5'-GCCATGCACAGGAAGTAGGTGAATATGAGCA -3' \\
9 & D417N forward & 5'-CTGGCCTTCGCCAACCTCTGCATGGGC -3' \\
10 & D417N reverse & 5'-GCCCATGCAGAGGTTGGCGAAGGCCAG-3' \\
11 & Y558F forward & 5'-GTCTGCGTCTGCTTCGGCCGCATCTAC-3' \\
12 & Y558F reverse & 5'-GTAGATGCGGCCGAAGCAGACGCAGAC-3' \\
\hline
\end{tabular}

Underlined nucleotides are sites of mutagenesis, while bold nucleotides shown the EcoRI and Xho/ restriction sites for cloning into the expression vector.

LHR, luteinizing hormone receptor. 


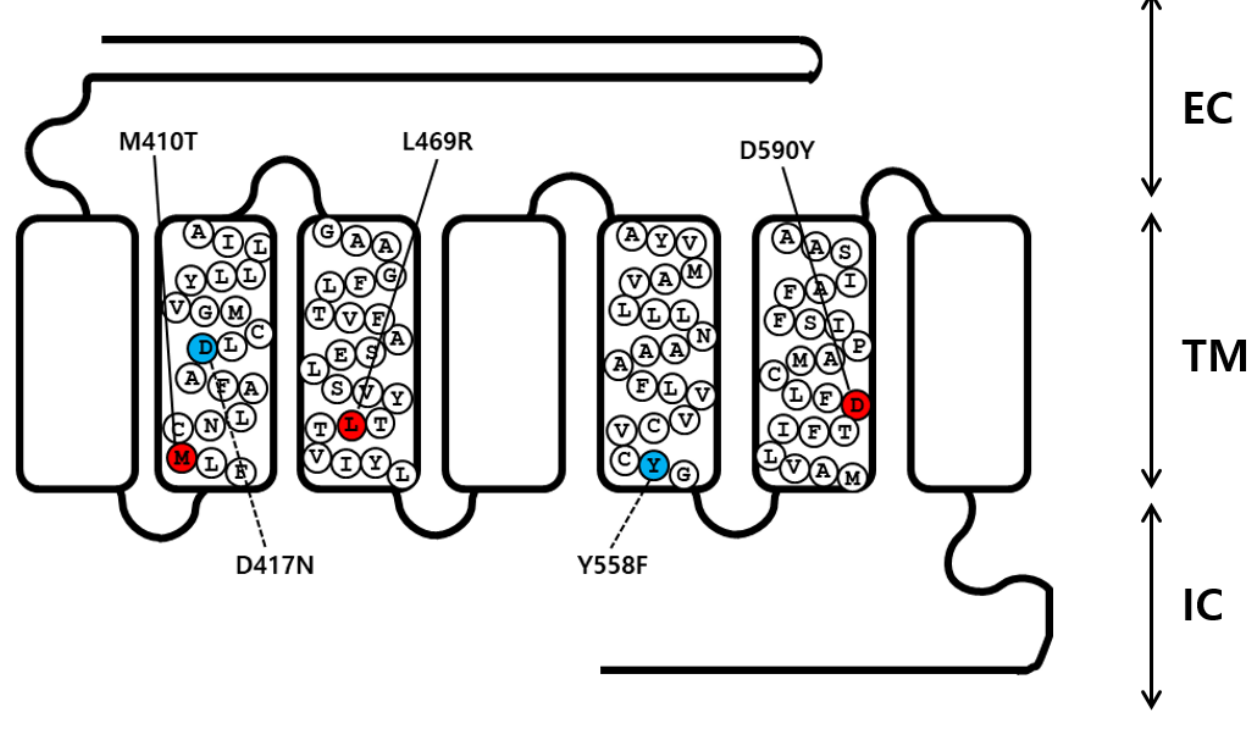

Fig. 1. Schematic representation of the eel LHR structure. The location of the 3 constitutively activating mutations (M410T, L469R, and D590Y) and the 2 inactivating mutations (D417N and Y558F) are indicated. Amino acid sequences at the mutated sites in the transmembrane domains of the eel LHR are shown. Alignment of the eel LHR sequence was performed using homologous mammalian LH/CGR sequences obtained from the NCBI database. The activating and inactivating sites were determined by comparison with the corresponding sites in the eel LHR. Red circles indicate constitutively activating mutations, whereas blue circles indicate inactivating mutations. EC, extracellular domain; TM, transmembrane domain; IC, intracellular domain; LHR, luteinizing hormone receptor.

\section{Transient transfection and production of recombinant eel luteinizing hormone}

CHO-K1 cells were cultured in growth medium (Ham's F-12 medium containing $2 \mathrm{mM}$ glutamine, $50 \mathrm{U} / \mathrm{mL}$ penicillin, $50 \mu \mathrm{g} / \mathrm{mL}$ streptomycin, and $10 \%$ fetal bovine serum [FBS]). Cells were grown to 80\%-90\% confluence in 6-well plates followed by transfection with mutant plasmids. CHO growth medium containing 20\% FBS was added to each well $5 \mathrm{~h}$ after transfection. Cells were used for cAMP analysis at $48 \mathrm{~h}$ after transfection.

For ligand production, the rec-eel LH expression vector was transfected into CHO-S cells using the FreeStyle ${ }^{\mathrm{TM}} \mathrm{MAX}$ reagent transfection method according to the manufacturer's instructions, and as was previously reported in our lab (Byambaragchaa et al., 2018). On the day of transfection, cell density was approximately $1.2-1.5 \times 10^{6}$ cells $/ \mathrm{mL}$. The FreeStyle ${ }^{\mathrm{TM}}$ MAX Reagent and eel LH plasmid were diluted, and gently mixed by inverting the tube. The DNA-FreeStyle ${ }^{\mathrm{TM}} \mathrm{MAX}$ reagent was incubated for $10 \mathrm{~min}$ at $25^{\circ} \mathrm{C}$ to allow the formation of complexes. The complexes were added to $200 \mathrm{~mL}$ of cell-containing medium. Culture media were collected on day 7 after transfection; supernatants were collected and frozen at $-80^{\circ} \mathrm{C}$.

\section{Analysis of recombinant eel luteinizing hormone}

Rec-eel LH was quantified using a double-sandwich enzyme-linked immunosorbent assay (ELISA) performed in plates coated with the 5A11 monoclonal antibody, as previously described (Kim et al., 2016). A volume of $100 \mu \mathrm{L}$ of the rec-eel LH sample was added to the wells and then incubated for $1 \mathrm{~h}$ at $25^{\circ} \mathrm{C}$. After washing 3 times with PBS-T, HRP-conjugated anti-eel11A8 antibody in PBS was added to the plates and they were incubated for $1 \mathrm{~h}$ at $25^{\circ} \mathrm{C}$. After washing, wells were incubated with $100 \mu \mathrm{L}$ of substrate solution for $20 \mathrm{~min}$ at $25^{\circ} \mathrm{C}$. The reaction was stopped by adding stop solution $\left(50 \mu \mathrm{L}\right.$ of $\left.1 \mathrm{M} \mathrm{H}_{2} \mathrm{SO}_{4}\right)$. Absorbance at $450 \mathrm{~nm}$ was measured in 
each well using a microplate reader Cytation 3 (BioTek, Winooski, VT, USA).

\section{Analysis of cyclic adenosine monophosphate by homogeneous time-resolved fluorescence (HTRF)}

The accumulation of cAMP in CHO-K1 cells expressing WT and mutant eel LHRs was measured using cAMP Dynamic 2 assay kits (Cisbio Bioassays, Codolet, France), as previously described (Byambargchaa et al., 2018). Briefly, cells transfected with WT and mutant eel LHRs were added at 10,000 cells per well into a 384-well plate $48 \mathrm{~h}$ after transfection. Cells were stimulated by incubation with the agonist for $30 \mathrm{~min}$ at $25^{\circ} \mathrm{C}$. cAMP level was detected by measuring the decrease in HTRF energy transfer $(665 \mathrm{~nm} / 620 \mathrm{~nm})$ using an Artemis K-101 HTRF microplate reader (Kyoritsu Radio, Tokyo, Japan). The specific signal-Delta F (energy transfer) is inversely proportional to the concentration of cAMP in the standard or sample. Results were calculated based on the $665 \mathrm{~nm} / 620 \mathrm{~nm}$ ratio and expressed as Delta F\% (cAMP inhibition), according to the following equation: [Delta $\mathrm{F} \%=$ (standard or sample ratio - sample negative $) \times$ 100 / ratio negative]. The cAMP concentrations were calculated from the Delta F\% values using the Prism software (GraphPad, La Jolla, CA, USA).

\section{Data analysis}

The MultAlin interface-multiple sequence alignment software was used for sequencing results. The GraphPad Prism 6.0 was used for the analysis of the production of cAMP and GraFit 5.0 (Erithacus Software Limited, Surrey, UK) was used for the cAMP EC $\mathrm{E}_{50}$ values and analyses of stimulation curves. Curves fitted in a triplicate experiment were normalized to the background signal measured for mock-transfected cells. One-way ANOVA and Turkey's Multiple Comparison tests were used to compare the results between samples, using GraphPad Prism 6.0. Differences were indicated as significant between the groups $(p<0.05)$.

\section{RESULTS}

\section{Construction of wild type and mutant eel luteinizing hormone receptors}

As previously reported, the eel LHR is known to consist of 2115 nucleotides encoding 705 amino acids (Byambaragchaa et al., 2018). In order to generate substitute mutations at target amino acids, we used an overlap extension PCR strategy with primers designed to change target nucleotides. To investigate the effects on the interaction of hormones to the receptor in the eel LHR activation system, we generated 3 constitutively activating mutations in the II, III, and VI transmembrane helices of LHR. These mutant receptors were designated M410T, L469R, and D590Y. We also constructed 2 inactivating mutations of eel LHR, designated as D417N and Y546F in the II and V transmembrane helices, respectively (Fig. 1).

\section{Basal and eel LH-stimulated activities of eel LHR constitutively activating mutants}

The effects of activating mutations on the basal and eel LH-stimulated cAMP responsiveness are summarized in Fig. 2A. The basal and Rmax cAMP responses in WT receptor were demonstrated to be 1.2 and $87.5 \mathrm{nM} / 10^{4}$ cells, respectively. The production of cAMP was exhibited an increased in a dose-dependent manner. The $\mathrm{EC}_{50}$ value of the eel LH-stimulated cAMP response was shown to be approximately $18.9 \mathrm{ng} / \mathrm{mL}$. In cells expressing the constitutively activating mutants (M410T, L469R, and D590Y) the induced basal cAMP responsiveness was increased by $4.8 \pm 0.3$, $22.9 \pm 1.5$, and $9.3 \pm 0.8 \mathrm{ng} / 10^{4}$ cells, respectively (Fig. $2 \mathrm{~B}$ and Table 2). In contrast to $\mathrm{CHO}-\mathrm{K} 1$ cells 
A
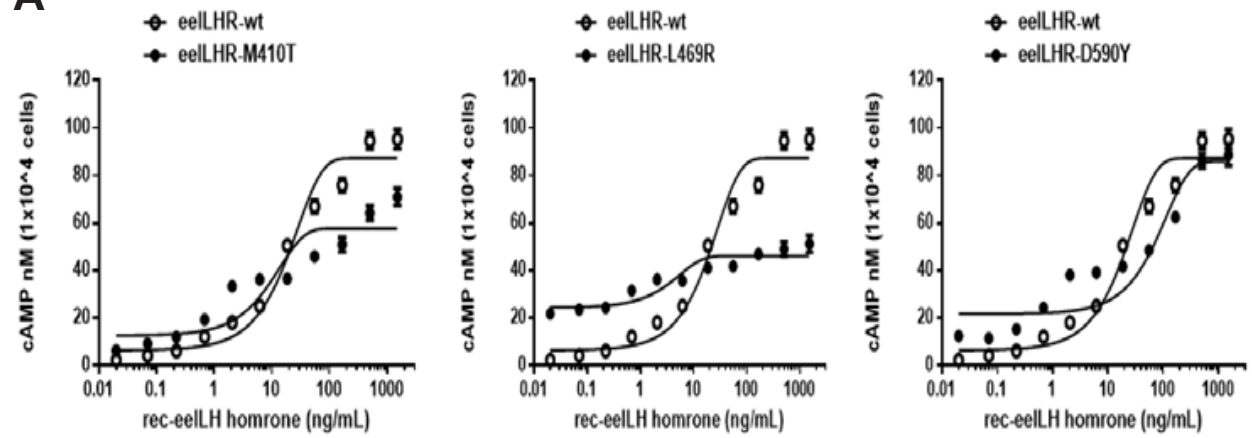

B
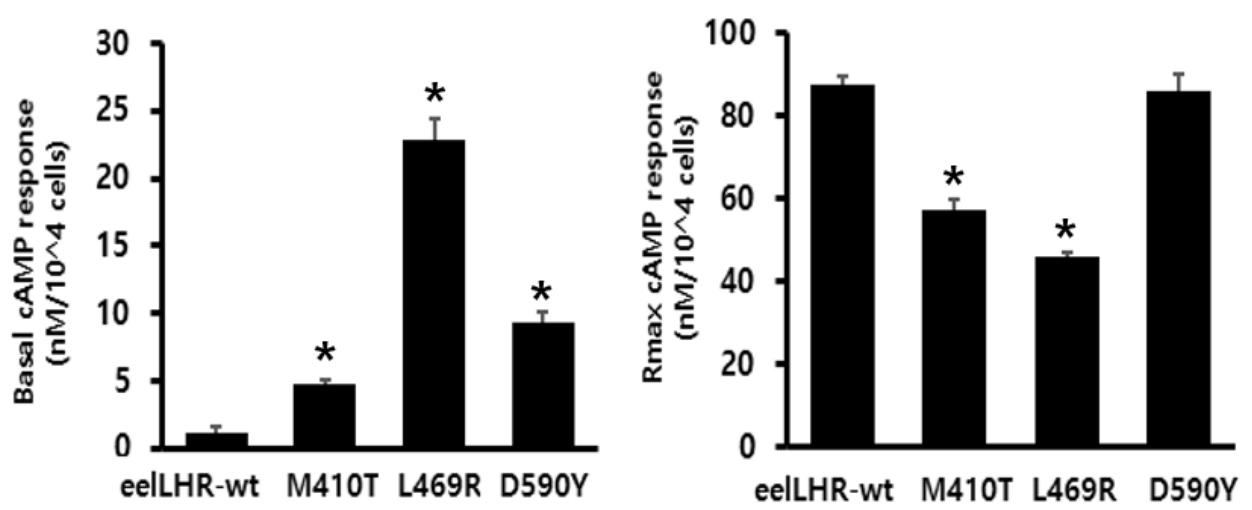

Fig. 2. Total levels of cAMP stimulated by eel LH in CHO-K1 cells transfected with constitutively activating eel LHR mutants. (A) CHO-K1 cells transiently transfected with wild type and activating mutations (M410T, L469R, and D590Y) of the eel LHR were stimulated with eel LH $(0-1,000 \mathrm{ng} / \mathrm{mL})$ for $30 \mathrm{~min}$. The production of CAMP was detected using a homogenous time-resolved fluorescence (HTRF) assay. The accumulation of cAMP was calculated as Delta F\%. The concentration of cAMP was recalculated using the GraphPad Prism software. The mock-transfected results were subtracted from each data set. (B) Basal cAMP response without agonist and maximal cAMP response were presented using bar graphs. * Statistically significant differences $(p<0.05)$ when compared with the wild type receptor. A representative data is shown as the mean of two independent experiments. CAMP, cyclic adenosine monophosphate; LHR, luteinizing hormone receptor.

Table 2. Bioactivity of eel $\mathrm{LH}$ receptors in cells expressing activating receptor mutants

\begin{tabular}{|c|c|c|c|}
\hline \multirow[b]{2}{*}{ Eel LH receptors } & \multicolumn{3}{|c|}{ cAMP responses } \\
\hline & $\begin{array}{c}\text { Basal' } \\
\text { (nM/10 cells) }\end{array}$ & $\begin{array}{c}E C_{50} \\
(\mathrm{ng} / \mathrm{mL})\end{array}$ & $\begin{array}{c}\mathrm{Rmax}^{2)} \\
\text { (nM/104 cells) }\end{array}$ \\
\hline Eel LHR-wt & $\begin{array}{l}1.2 \pm 0.5 \\
\text { (1-fold) }\end{array}$ & $\begin{array}{c}18.9 \\
(15.3 \text { to } 24.9)^{3)}\end{array}$ & $\begin{array}{c}87.5 \pm 2.2 \\
\text { (1-fold) }\end{array}$ \\
\hline Eel LHR-M410T & $\begin{array}{c}4.8 \pm 0.3 \\
(4.0 \text {-fold })\end{array}$ & $\begin{array}{c}8.7 \\
(5.5 \text { to } 20.1)\end{array}$ & $\begin{array}{c}57.3 \pm 2.6 \\
\text { (0.65-fold) }\end{array}$ \\
\hline Eel LHR-L469R & $\begin{array}{c}22.9 \pm 1.5 \\
\text { (19.1-fold) }\end{array}$ & $\begin{array}{c}3.8 \\
\text { (2.4 to } 8.1)\end{array}$ & $\begin{array}{l}46.2 \pm 1.1 \\
(0.52 \text {-fold })\end{array}$ \\
\hline Eel LHR-D590Y & $\begin{array}{l}9.3 \pm 0.8 \\
(7.8 \text {-fold })\end{array}$ & $\begin{array}{c}77.3 \\
\text { (52.5 to } 147)\end{array}$ & $\begin{array}{c}85.9 \pm 4.1 \\
\text { (0.98-fold) }\end{array}$ \\
\hline
\end{tabular}

Values are the means \pm SEM of triplicate experiments. $\mathrm{EC}_{50}$ values were determined from the concentration-response curves obtained in vitro bioassays.

1) Basal average level of CAMP without treatment with agonist.

${ }^{2)}$ Rmax average level of $\mathrm{CAMP} / 10^{4}$ cells.

${ }^{3)}$ Geometric mean (95\% confidence limit).

cAMP, cyclic adenosine monophosphate; LHR, luteinizing hormone receptor. 
harboring the WT receptor, cells expressing the M410T mutant exhibited a 4.8-fold increase in basal production of cAMP, indicating that the receptor was constitutively active. In addition, cells expressing the L469R and D590Y mutants exhibited a 19.1- and 7.8-fold increase in the amounts of basal cAMP, respectively, as compared to those of cells expressing the WT eel LHR (Table 2).

We noted that eel LH produced a concentration-dependent increase in the production of cAMP in cells expressing the activating mutants (M410T, L469R, and D590Y), with an $\mathrm{EC}_{50}$ (50\% effective concentration) of $8.7 \mathrm{ng} / \mathrm{mL}, 3.8 \mathrm{ng} / \mathrm{mL}$, and $77.3 \mathrm{ng} / \mathrm{mL}$, respectively. The maximum cAMP response induced by eel LH in the activating mutants (M410T, L469R, and D590Y) with respect to the maximal response of the WT was found to be approximately $0.65-, 0.52-$, and 0.98 fold, respectively. Cells expressing the M410T and L469R mutants were shown to not respond to further stimulation by higher concentrations of agonist. However, the D590Y mutant was observed to reach approximately $98 \%$ of the maximal response of the WT.

The concentration-response curve of the accumulation of cAMP in eel LHR-D590Y was characterized by a 4 -fold increase in the $\mathrm{EC}_{50}$, but no change in the maximal response when compared with cells expressing WT receptor. Thus, compared with the WT eel LHR, the 3 activating mutations were demonstrated to produce a higher basal cAMP response in CHO-K1 cells, consistent with constitutive activation of the receptor. The mutant exhibiting the highest level of basal production of cAMP (L469R) was found to not react to eel LH with a further increase in maximal cAMP responsiveness. The basal production of cAMP in the L469R mutant represented $49 \%$ of the maximal stimulation produced by eel LH (Table 2). Thus, the high basal production of cAMP in the L469R mutant prevented a further increase in the cAMP responsiveness despite a higher agonist stimulation.

\section{Basal and eel LH-stimulated activities of eel LHR inactivating mutants}

To directly assess the functional effects of the 2 inactivating mutations, we transiently expressed these mutant receptors in $\mathrm{CHO}-\mathrm{K} 1$ cells. The $\mathrm{D} 417 \mathrm{~N}$ and $\mathrm{Y} 558 \mathrm{~F}$ mutants were evaluated by quantifying the cAMP stimulation in cells incubated with increasing concentrations of eel LH. As predicted, the cAMP signaling was impaired in cells expressing both mutant receptors compared with those expressing the WT receptor. The basal cAMP response was shown to not be affected by the inactivating mutations, and showed little increase under high concentration of eel $\mathrm{LH}$.

The $\mathrm{EC}_{50}$ value exhibited an approximately 2.6-fold decrease in $\mathrm{D} 417 \mathrm{~N}$ mutant compared with that of the WT eel LHR. However, the maximal response of this mutant was demonstrated to only be $33 \%$ of the response of the WT eel LHR (Fig. 3A). In the Y558F mutant, the $\mathrm{EC}_{50}$ value was also shown to exhibit a 2.2-fold decrease of the value of the WT eel LHR; however, the maximal response was only $25 \%$ of that of the WT (Fig. 3B). As shown in Table 3, the signal responsiveness of the receptors was severely affected by the inactivating mutations. The maximal response of these cells was observed to be 67\%-75\% lower than the maximal response of cells expressing the WT eel LHR.

\section{DISCUSSION}

The present study was designed to determine the possibility that the activation/inactivation of eel LHRs might be necessary for the signal transduction induced by ligand agonist. In the present study, our results showed that the three activating mutations, eel LHR-M410T, -L469R, and -D590Y, resulted in a distinctly increased basal cAMP response, suggesting that these mutations might cause the constitutive activation of the eel LHR .

Cells expressing the hLHR-M398T mutant (equivalent to M410T in the eel LHR) 

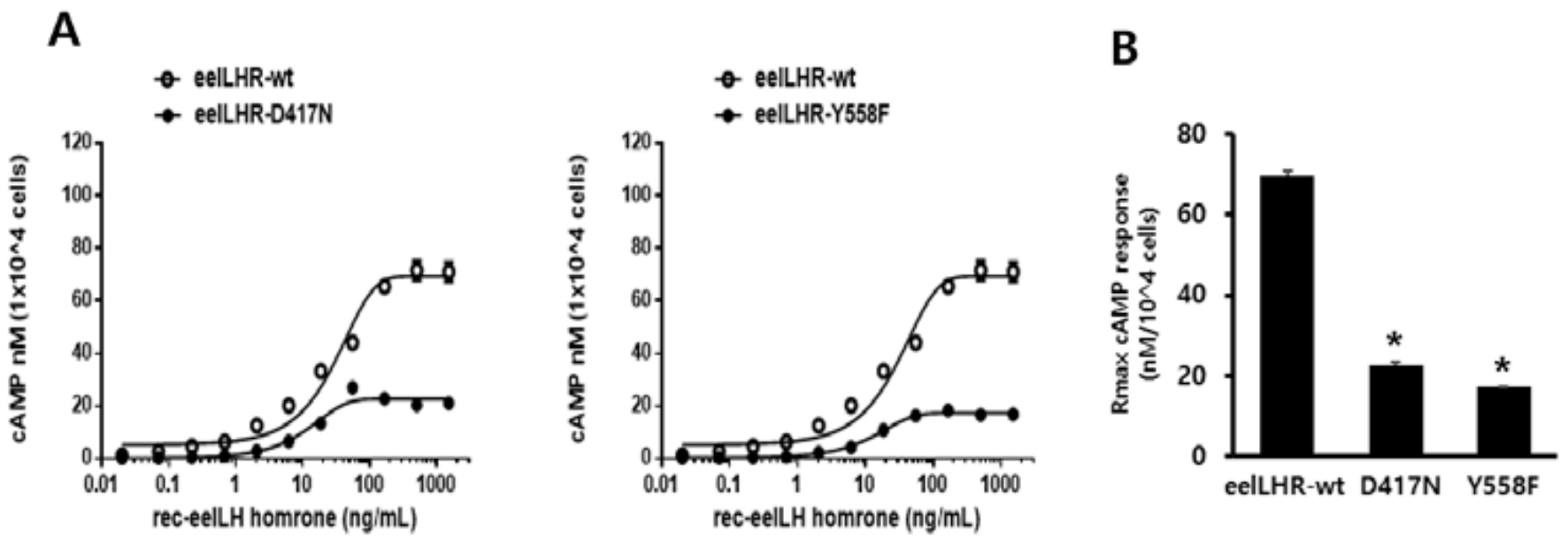

Fig. 3. Production of cAMP stimulated by treatment with eel LH in CHO-K1 cells transfected with inactivating eel LHR mutants. (A) CHO-K1 cells transiently transfected with wild type and inactivating mutant (D417N and Y558F) eel LHRs were stimulated with eel LH (0-1,000 ng/mL) for 30 min. Total levels of CAMP were analyzed using a homogenous time-resolved fluorescence (HTRF) assay. Empty circles denote wild-type eel LHR, whereas black circles denote mutants. Data was subtracted from the results of the mock-transfected cells. (B) The maximal cAMP response is presented by a bar graph. * Statistically significant differences $(p<0.05)$ when compared with the wild type receptor. A representative data set performed in triplicate out of 2 independent experiments. cAMP, cyclic adenosine monophosphate; LHR, luteinizing hormone receptor.

Table 3. Bioactivity of eel LH receptors in cells expressing inactivating receptor mutants

\begin{tabular}{lccc}
\hline \hline Eel LH receptors & \multicolumn{3}{c}{ cAMP responses } \\
\cline { 2 - 4 } & $\begin{array}{c}\text { Basal }^{1)} \\
\left(\mathrm{nM} / 10^{4} \text { cells }\right)\end{array}$ & $\begin{array}{c}\mathrm{EC}_{50} \\
(\mathrm{ng} / \mathrm{mL})\end{array}$ & $\begin{array}{c}\left.\mathrm{Rmax}^{2}\right) \\
\left(\mathrm{nM} / 10^{4} \text { cells }\right)\end{array}$ \\
\hline Eel LHR-wt & $2.6 \pm 0.1$ & 31.7 & $69.5 \pm 1.5$ \\
Eel LHR-D417N & $1.2 \pm 0.1$ & $(26.1 \text { to } 40.6)^{3)}$ & $22.7 \pm 0.6$ \\
Eel LHR-Y558F & $0.7 \pm 0.1$ & 11.9 & $(0.33$-fold $)$ \\
& & $(9.4$ to 16.5$)$ & $17.3 \pm 0.2$ \\
& 13.8 & $(0.25$-fold $)$ \\
\hline
\end{tabular}

Values are the means $\pm S E M$ of triplicate experiments. $E_{50}$ values were determined from the concentration-response curves obtained in vitro bioassays

1) Basal average level of CAMP without treatment with agonist.

${ }^{2)}$ Rmax average level of $\mathrm{CAMP} / 10^{4}$ cells.

3) Geometric mean ( $95 \%$ confidence limit).

cAMP, cyclic adenosine monophosphate; LHR, luteinizing hormone receptor.

exhibited high basal levels of cAMP (Yano et al., 1996). Our results also described the M410T constitutively activating mutation in the eel LHR, which was shown to be located in the same second transmembrane region. However, the maximal cAMP response was observed to reach only $65 \%$ of the activity detected in cells expressing the WT receptor. The hLHR-L457R mutation (equivalent to L469R in eel LHR) was the first activating mutation identified in hLHR and cells expressing this mutant receptor were noted to exhibit markedly higher basal levels of cAMP (7- to 14-fold) relative to those harboring the WT receptor (Latronico et al., 1998; Galet \& Ascoli., 2006; Latronico \& Segaloff., 2007; Zhang et al., 2007). Previous results from our colleagues have also shown that basal cAMP responses in cells expressing the rLHR-L435R (equivalent to L469R in eel LHR) displayed a 47-fold increase in the absence of agonist, without leading a further increase in the cAMP response following stimulation by hCG (Min et al., 1998). Previous studies also reported that hLHR-L457R and hFSHR-L460R mutants resulted in strong constitutive activation 
(Tao et al., 2000; Zhang et al., 2007). However, hFSHR constitutively activating mutants were not as active as hLHR mutants containing the comparable mutation. These results were consistent with our current data, showing a remarkable increase (19.1-fold) in the basal cAMP response of cells expressing the eel LHR-L469R mutant. However, the maximal cAMP response to agonist was shown to be approximately $52 \%$ of the WT receptor, as previously described in hLHR (Dhanwada et al., 1996; Huhtaniemi 2000; Huhtaniemi \& Themmen, 2005). Hence, we suggested that the L469R mutant did not increase its maximal cAMP responsiveness despite treatment with a high concentration of agonist. Thus, the activating eel LHR-L457R mutant could serve as a specific model in figuring out the basic molecular mechanisms of the activation of eel LHR induced by treatment with high concentration of agonist.

Several years ago, the hLHR-D578Y and -D578G mutants (equivalent to D590Y in the eel LHR) were first reported to be inherited in an autosomal dominant manner, indicating that D578G mutant displayed high basal cAMP response (Shenker et al., 1993; Shenker, 2002). Previous our studies have also reported that rLHR-D556Y (equivalent to D590Y in eel LHR) resulted in a high increase in the concentration of basal cAMP responses with the maximal cAMP response to hCG being about 75\% of that of the WT receptor (Min et al., 1998). These results on the hLHR-D578Y and rLHR-D556Y were consistent with our results, indicating that eel LHRD590Y displayed a high basal cAMP response, and exhibited a maximal cAMP response similar to that of the WT receptor. Thus, our results suggested that the D590Y mutant has a specific characteristic compared with the M410T and L469R mutants, which were markedly decreased in their maximal cAMP activity. This suggested that activating mutations, including eel LHR-M410T, -L469R, and -D590Y might not be unique for the species, and that the basal cAMP response would be markedly increased irrespective of whether these mutants are expressed in mammals (human and rat) or fish.

In the case of the inactivating mutants, we mutated the highly conserved amino acids present in the second (eel LHR-D417) and fifth (eel LHR-Y558) transmembrane helices to asparagine and phenylalanine, respectively. As predicted from results obtained with hLHR and rLHR (Quintana et al., 1993; Min et al., 1998; Tao, 2006), these mutations (eel LHR-D417N and eel LHR-Y558F) were expected to impair signal transduction. Previous studies reported that cells expressing rLHRD383N displayed a rightward shift in the $\mathrm{EC}_{50}$ for cAMP stimulation, but normal maximal levels (Dhanwada et al., 1996). These results were consistent with our data, showing that eel LHR$\mathrm{D} 417 \mathrm{~N}$ and $-\mathrm{Y} 546 \mathrm{~F}$ were signaling-impairing mutations. However, the maximal response was found to be a little different from our results, displaying only $25 \%-33 \%$ of the maximal response of WT eel LHR. In the present study, the eel LH-induced increase of the production of cAMP in cells harboring the eel LHR-D417N and -Y558F mutations did not completely impair signal transduction. These inactivating mutants were assumed to impair the signal transduction through conformational changes following the formation of the receptor-ligand complexes despite the prolonged treatment with the agonist. These results suggested that the distinct configurations of these mutants induced different signal transduction pathways, resulting in different maximal cAMP responses to LH. The results presented here showed for the first time that three constitutively activating mutants of eel LHR were able to conclusively effect the basal cAMP response.

In conclusion, this study shows that constitutively activating mutations in eel LHR (M410T, L469R, and D590Y) resulted in a significant increase in the basal cAMP production, but cAMP production did not respond to eel $\mathrm{LH}$ stimulation with a concentration-dependent increase in M410T and L469R. In contrast, the inactivating mutations (D417N and Y558F) demonstrated to not completely impair the signal transduction. Thus, we suggested that the activation process might involve an agonist-induced conformational change in the receptor. The fundamental mechanisms 
through which the constitutively activating mutants resulted in a significant increase in the basal cAMP response, whereas the inactivation mutants that impaired signal transduction require further investigation. Future studies using these glycoprotein hormone receptors could provide very valuable information regarding the structure-function relationship of LHR-LH complexes in signal transduction.

\section{REFERENCES}

Althumairy D, Zhang X, Baez N, Barisas G, Roess DA, Bousfield GR, Crans DC (2020) Glycoprotein G-protein coupled receptors in disease: Luteinizing hormone receptors and follicle stimulating hormone receptors. Diseases 8:35.

Ascoli M, Fanelli F, Segaloff DL (2002) The lutropin/choriogonadotropin gonadotropin receptor, a 2002 perspective. Endocr Rev 23:141-174.

Byambaragchaa M, Kim DJ, Kang MH, Min KS (2018) Site specificity of eel luteinizing hormone N-linked oligosaccharides in signal transduction. Gen Comp Endocrinol 268:50-56.

Byambaragchaa M, Kim JS, Park HK, Kim DJ, Hong SM, Kang MH, Min KS (2020) Constitutive activation and inactivation of mutations inducing cell surface loss of receptor and impairing of signal transduction of agonist-stimulated eel follicle-stimulating hormone receptor. Int J Mol Sci 21:7075.

Dhanwada KR, Vijapurkar U, Ascoli M (1996) Two mutations of the lutropin/choriogonadotropin receptor that impair signal transduction also interfere with receptor-mediated endocytosis. Mol Endocrinol 10:544-554.

Galet C, Ascoli M (2006) A constitutively active mutant of the human lutropin receptor (hLHRL457R) escapes lysosomal targeting and degradation. Mol Endocrinol 20:2931-2945.

Huhtaniemi I (2000) Activating and inactivating hormone receptor mutations. Horm Res 53:S9S16.

Huhtaniemi IT, Themmen AP (2005) Mutations in human gonadotropin and gonadotropinreceptor genes. Endocrine 26:207-217.

Ignacak M, Hilczer M, Zarzycki J, Trzeciak WH (2000) Substitution of M398T in the second transmembrane helix of the LH receptor in a patient with familial male-limited precocious puberty. Endocr J 47:595-599.

Kim DJ, Park CW, Kim DW, Park HK, Byambaragchaa M, Lee NS, Hong SM, Seo MY, Kang MH, Min KS (2016) Production and characterization of monoclonal antibodies against recombinant tethered follicle-stimulating hormone from Japanese eel Anguilla japonica. Gen Comp Endocrinol 233:8-15.

Kim JM, Munkhuu O, Byambaragchaa M, Lee BI, Kim SK, Kang MH, Kim DJ, Min KS (2019) Site-specific roles of $\mathrm{N}$-linked oligosaccharides in recombinant eel follicle-stimulating hormone for secretion and signal transduction. Gen Comp Endocrinol 276:37-44.

Kraaij R, Post M, Kremer H, Milgrom E, Epping W, Brunner HG, Grootegoed JA, Themmen AP (1995) A missense mutation in the second transmembrane segment of the luteinizing hormone receptor causes familial male-limited precocious puberty. J Clin Endocrinol Metab 80:31683172.

Kudo M, Osuga Y, Kobilka BK, Hsueh AJ (1996) Transmembrane regions V and VI of the human luteinizing hormone receptor are required for constitutive activation by a mutation in the third intracellular loop.J Biol Chem 271:22470-22478.

Latronico AC, Chai Y, Arnhold IJ, Liu X, Mendonca BB, Segaloff DL (1998) A homozygous 
microdeletion in helix 7 of the luteinizing hormone receptor associated with familial testicular and ovarian resistance is due to both decreased cell surface expression and impaired effector activation by the cell surface receptor. Mol Endocrinol 12:442-450.

Latronico AC, Segaloff DL (2007) Insights learned from L457 $7^{(3.43)} \mathrm{R}$, an activating mutant of the human lutropin receptor. Mol Cell Endocrinol 260-262:287-293.

McGee SR, Narayan P (2013) Precocious puberty and Leydig cell hyperplasia in male mice with a gain of function mutation in the LH receptor gene. Endocrinology 154:3900-3913.

Meehan TP, Narayan P (2007) Constitutively active luteinizing hormone receptors: Consequences of in vivo expression. Mol Cell Endocrinol 260-262:294-300.

Min KS, Liu X, Fabritz J, Jaquette J, Abell AN, Ascoli M (1998) Mutations that induce constitutive activation and mutations that impair signal transduction modulate the basal and/or agoniststimulated internalization of the lutropin/choriogonadotropin receptor. J Biol Chem 273:34911-34919.

Quintana J, Wang H, Ascoli M (1993) The regulation of the binding affinity of the luteinizing hormone/choriogonadotropin receptor by sodium ions is mediated by a highly conserved aspartate located in the second transmembrane domain of $\mathrm{G}$ protein-coupled receptors. Mol Endocrinol 7:767-775.

Segaloff DL, Ascoli M (1993) The lutropin/choriogonadotropin receptor... 4 years later. Endocr Rev 14:324-347.

Shenker A (2002) Activating mutations of the lutropin choriogonadotropin receptor in precocious puberty. Recept Channels 8:3-18.

Shenker A, Laue L, Kosugi S, Merendino JJ Jr, Minegishi T, Cutler GB Jr (1993) A constitutively activating mutation of the luteinizing hormone receptor in familial male precocious puberty. Nature 365:652-654.

Tao YX (2006) Inactivating mutations of G protein-coupled receptors and diseases: Structurefunction insights and therapeutic implications. Pharmacol Ther 111:949-973.

Tao YX, Abell AN, Liu X, Nakamura K, Segaloff DL (2000) Constitutive activation of G protein-coupled receptors as a result of selective substitution of a conserved leucine residue in transmembrane helix III. Mol Endocrinol 14:1272-1282.

Wu SM, Leschek EW, Rennert OM, Chan WY (2000) Luteinizing hormone receptor mutations in disorders of sexual development and cancer. Front Biosci 5:D343-D352.

Yano K, Kohn LD, Saji M, Kataoka N, Okuno A, Cutler GB Jr (1996) A case of male-limited precocious puberty caused by a point mutation in the second transmembrane domain of the luteinizing hormone choriogonadotropin receptor gene. Biochem Biophys Res Commun 220:1036-1042.

Zhang M, Mizrachi D, Fanelli F, Segaloff DL (2005) The formation of a salt bridge between helices 3 and 6 is responsible for the constitutive activity and lack of hormone responsiveness of the naturally occurring L457R mutation of the human lutropin receptor. J Biol Chem 280:26169-26176.

Zhang M, Tao YX, Ryan GL, Feng X, Fanelli F, Segaloff DL (2007) Intrinsic differences in the response of the human lutropin receptor versus the human follitropin receptor to activating mutations. J Biol Chem 282:25527-25539. 
